\title{
Biotechnological approaches to reduce biogenic risks in crop production: potato case
}

\author{
Svetlana M. Lenivko*, Vladimir I. Boiko \\ Brest State A.S. Pushkin University, Brest, Republic of Belarus \\ *Corresponding author: lenivko@brsu.brest.by
}

\begin{abstract}
The article presents an overview of the biogenic agro-ecological risks in crop production, to reduce which it is possible to use biotechnological approaches. Ways to reduce the negative impact of the two most common harmful objects, the colorado potato beetle (Leptinotarsa decemlineata Say) and phytophthoras (Phytophthora infestans (Mont.) De Bary), which lead to significant losses of potato yield, are considered. It is shown that the currently used methods of plant cell engineering (somatic hybridization and microclonal reproduction) are environmentally sound biotechnological methods of controlling black eye rot potato. The need to develop genetically engineered methods is associated with an exacerbation of biogenic agroecological risks, the reduction of which is an important approach is a proactive introgressive breeding strategy based on cell engineering and molecular methods.
\end{abstract}

Key words: biogenic agro-ecological risks, microclonal propagation, transgenic plants, Solanum tuberosum L., Leptinotarsa decemlineata Say, Phytophthora infestans (Mont.) de Bary

Article history:

Received: 7 August 2019. Accepted: 28 November 2019

For citation:

Lenivko SM, Boiko VI. Biotechnological approaches to reduce biogenic risks in crop production: potato case. RUDN Journal of Agronomy and Animal Industries. 2019; 14(4):403 - 422. doi: 10.22363/2312-797X-2019-14-4-403-422

\section{Биотехнологические подходы, снижающие биогенные риски в растениеводстве, на примере картофеля}

\author{
С.М. Ленивко*, В.И. Бойко \\ Брестский государственный университет имени А.С. Пушкина \\ Брест, Республика Беларусь \\ *lenivko@brsu.brest.by
}

Аннотация. Приведен обзор биогенных агроэкологических рисков в растениеводстве, для снижения которых возможно использование биотехнологических подходов. Рассмотрены пути, предлагаемые современной биотехнологией, для снижения негативного влияния двух наиболее

(С) Ленивко С.М., Бойко В.И., 2019.

(c) This work is licensed under a Creative Commons Attribution 4.0 International License https://creativecommons.org/licenses/by/4.0/ 
распространенных вредоносных объектов: колорадского жука (Leptinotarsa decemlineata Say) и фитофторы (Phytophthora infestans (Mont.) de Bary), приводящих к значительным потерям урожая картофеля. Проведен анализ возможных потенциальных рисков, связанных с использованием трансгенных организмов. Показано, что применяемые в настоящее время методы клеточной инженерии растений (соматическая гибридизация и микроклональное размножение) являются экологически оправданными биотехнологическими способами борьбы с фитофторозом. Потребность разработки генно-инженерных методов связана с обострением биогенных агроэкологических рисков, для снижения которых эффективна стратегия упреждающей интрогрессивной селекции, основанной на клеточноинженерных и молекулярных методах.

Ключевые слова: биогенные агроэкологические риски, микроклональное размножение, трансгенные растения, Solanum tuberosum L., Leptinotarsa decemlineata Say, Phytophthora infestans (Mont.) de Bary

\section{История статьи:}

Поступила в редакцию: 7 августа 2019 г. Принята к публикации: 28 ноября 2019 г.

\section{Для цитирования:}

Ленивко С.М., Бойко В.И. Биотехнологические подходы, снижающие биогенные риски в растениеводстве, на примере картофеля // Вестник Российского университета дружбы народов. Серия: Агрономия и животноводство. 2019. Т. 14. № 4. С. 403-422. doi: 10.22363/2312-797Х2019-14-4-403-422

\section{Potato productivity in the Republic of Belarus and Russia}

Against the background of increasing potential risks due to adverse changes occurring in the biosphere, one of the most important tasks is to obtain high crop yields. Efficiency of all agricultural production directly depends on productivity of crop production. A plant organism that can transform the energy of the sun into the energy of organic compounds is a fundamental link in production of food, feed, raw materials, fuel, and medicines. Intensification of crop production in modern conditions should be based on a reasonable combination of traditional approaches with new technologies.

Potato (Solanum tuberosum L.) is the second most important agricultural crop in the Republic of Belarus, only in the last five years slightly inferior to rapeseed. The Brest region steadily ranks second in lands under potato in farms of all categories. However, according to Belstat (Fig. 1), potato yields in the Brest region are reduced in comparison with this indicator for the Republic of Belarus and a number of regions.

Problem of productivity in potato industry of the Republic of Belarus and Russia is aggravated against the background of observed tendency to reduce sown areas. Between 1995 and 2015, lands under potatoes in the Republic of Belarus decreased 2.3 fold, in Russia - 1.6 fold and they continue to decline annually (Table 1). Performance of potato production level, defined by the national doctrines of food security of the two countries, is impossible without yield increase. Despite the growth of this indicator in 2015 compared to 1995 (in the Republic of Belarus - by 48\%, in Russia - by 34\%), the average potato yield in two countries is several times lower than the average value for Western Europe (Table 2). According to statistics of the United Nations Food and Agriculture Organization (FAO), in Germany and the Netherlands - the largest potato producers among European countries - reduction of croplands over 20 years was not so high, and since 2015 there is an inverse trend. The high average potato yield in these countries makes it possible to achieve significant productivity in relatively small lands. 


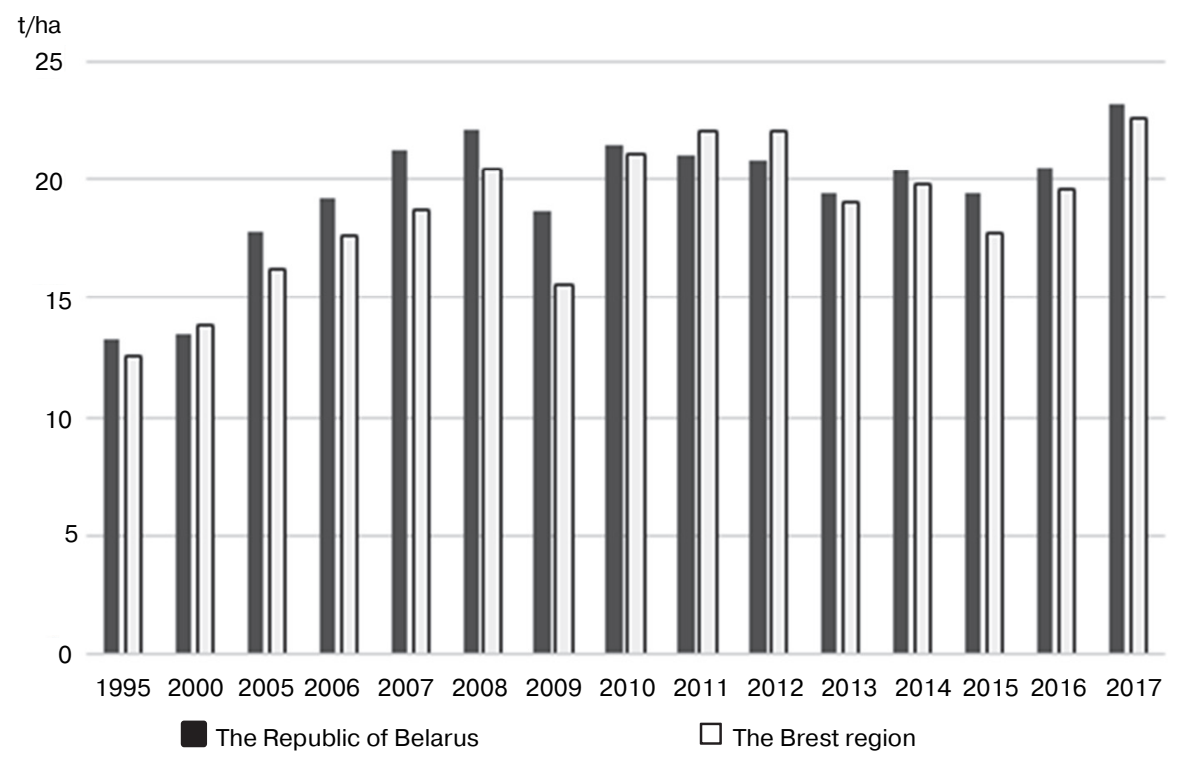

Fig. 1. Potato productivity in the Republic of Belarus and the Brest region in 1995-2017, t/ha [1]

Potato land dynamics in 1995-2017, thousand ha [2]

\begin{tabular}{|l|r|r|r|r|r|r|r|}
\hline \multicolumn{1}{|c|}{ Country } & \multicolumn{1}{c|}{1995} & \multicolumn{1}{c|}{2000} & \multicolumn{1}{c|}{2005} & \multicolumn{1}{c|}{2010} & \multicolumn{1}{c|}{2015} & \multicolumn{1}{c|}{2016} & 2017 \\
\hline Russia & 3390 & 2817 & 2273 & 2109 & 2112 & 2031 & 1889 \\
\hline Republic of Belarus & 725 & 661 & 461 & 367 & 310 & 292 & 276 \\
\hline Germany & 315 & 304 & 277 & 254 & 237 & 243 & 251 \\
\hline Netherlands & 179 & 180 & 156 & 157 & 156 & 156 & 161 \\
\hline
\end{tabular}

Potato yield dynamics in 1995-2017, t/ha [2]

\begin{tabular}{|l|c|c|c|c|c|c|c|}
\hline \multicolumn{1}{|c|}{ A country } & 1995 & 2000 & 2005 & 2010 & 2015 & 2016 & 2017 \\
\hline Russia & 11.8 & 10.5 & 12.4 & 10.0 & 15.9 & 15.3 & 15.7 \\
\hline Republic of Belarus & 13.1 & 13.2 & 17.7 & 21.4 & 19.4 & 20.5 & 23.2 \\
\hline Germany & 31.4 & 43.3 & 42.0 & 39.9 & 43.8 & 44.4 & 46.8 \\
\hline Netherlands & 41.0 & 45.7 & 43.4 & 43.6 & 42.7 & 42.0 & 46.0 \\
\hline Western Europe & 35.1 & 42.7 & 42.1 & 41.2 & 42.9 & 41.3 & 44.9 \\
\hline
\end{tabular}

The problem of low potato yields in the Republic of Belarus and Russia, apart from technological, organizational and economic factors, is directly related to the biogenic risks of cultivating this crop. The shortage of potato harvest is due to the increasing harmfulness of diseases caused by fungal, bacterial and viral pathogens, as well as insect pests. We consider the methods proposed by modern biotechnology to reduce the negative impact of the two most common harmful objects: the Colorado potato beetle (Leptinotarsa decemlineata Say) and phytophthora (Phytophthora infestans (Mont.) De Bary), which lead to significant losses in potato harvest. 


\section{Biotechnological approaches \\ in the control of late blight}

Late blight is one of the most harmful potato diseases. Blight affects aerial part of plants and thereby reduces assimilating surface during tuberization, and also causes rotting of tubers during storage. In the Republic of Belarus, strong outbreaks of the disease with $30 . .50 \%$ yield losses are observed every $2-3$ years.

The main late blight control methods, actively used for several decades of XX century and in the new century include cultivation of resistant potato varieties and fungicide application. The latter method, despite its effectiveness, is unsafe for human health and poses the problem of increasing chemical load on agrocenoses, and, as a consequence, deterioration of ecological state of the environment. Therefore, for sustainable development of potato growing in modern conditions, along with the use of effective agrotechnical measures, the creation of new potato varieties highly resistant to $P$. Infestans is required, which will significantly reduce chemical treatments during plant vegetation.

Resistance to $P$. infestans of previously developed varieties was determined by the presence of $\mathrm{R}$ genes transferred by the method of distant hybridization from wild potato variety Solanum demissum [3]. However, high variability of $P$. infestans manifested itself in formation of new pathogen forms capable of overcoming protective reactions of resistant varieties based on S. demissum R genes. According to Yu.T. Dyakova, frequency of spontaneous mutations in P. infestans at one locus per 1 ha reaches 1,000. It is a high pathogen mutation rate that can provide the level of variability necessary for all kinds of adaptations [4]. The process of variability has sharply intensified since 1984, when new phytophthora populations with two types of sexual process A1 and A2 migrated from Mexico to the area of intensive potato cultivation [3]. The appearance of the A2 type in the Republic of Belarus significantly aggravated harmfulness of late blight, because racial composition became more complicated, spectrum of virulence expanded, pathogen's aggressivity and its resistance to existing pesticides increased [5].

A promising strategy that opposes the rapid loss of potato resistance to late blight is creation of new varieties that retain high resistance to many races of late blight for a long time. Combination of several resistance genes from wild potato variety in one plant (gene pyramidation) makes resistance long-term, since the totality of transferred genes provides recognition of various pathogen races. A change in the racial composition of the pathogen in agrocenosis will not lead to a significant decrease in the productivity of plants with long-term resistance. Such selection is called proactive [6]. The effectiveness of potato introgressive selection can be improved by developing a new source material with complex resistance to late blight both of the aerial parts of the plant and tubers. A decisive role in increasing potato resistance to late blight is played by a targeted search for sources of valuable genes using marker-associated selection methods. Molecular markers make help to distinguish plant forms resistant to different pathotypes of the same pathogen, which significantly accelerates selection of resistant genotypes and their inclusion in the breeding process. 
Interspecific hybridization has been used in practical potato selection for several decades. Moreover, the transfer of resistance genes from wild species of the genus Solanum, growing in the Americas, to S. tuberosum during sexual hybridization is limited due to physiological and genetic incompatibility. Overcoming incompatibilities with the distant hybridization of cultured tetraploid potatoes with wild-growing species became possible thanks to the development of a number of biotechnological methods.

The method of somatic hybridization is based on the fusion of protoplasts isolated from somatic cells of various plant species under in vitro conditions. Somatic hybridization bypassing sexual process allows developing new source material (complex interspecific hybrids of three or more parent cells) with valuable traits from wild species to expand the genetic potential of potato breeding. The advantages of somatic hybridization include combining in one genome not only cultivated potato genes and phylogenetically distant wild relatives, which have more than 230 potatoes, but also cytoplasmic organelle genes (mitochondria, plastids), which ensures developing of qualitatively new interspecific hybrids [7]. Interspecific somatic potato hybrids are obtained in many countries, among which the Republic of Belarus. Somatic hybrids with 10 wild potato species inaccessible for sexual hybridization have been developed at Scientific and Practical Center for Potato, Vegetable and Fruit Growing (National Academy of Sciences of Belarus) by somatic hybridization. Despite the attractiveness of somatic hybridization, development of plant varieties, including potatoes, obtained on the basis of somatic hybrids, remains a rare phenomenon, since there is a problem with fertility of somatic hybrids and their ability to generate viable offspring when crossed with cultivated potatoes [8].

Another environmentally effective biotechnological method of controlling tuber blight, which reduces quality of planting material during storage, is the method of microclonal propagation of test-tube plants, which allows to obtain in sufficient quantities material free from fungal, and viral pathogens.

Microclonal propagation makes it possible to obtain genetically identical clone plants under in vitro conditions. It includes three stages: introduction of a cloned plant into explant culture; plant regeneration and its propagation in the required number of copies; stimulation of root formation in microplants and their adaptation to in vivo conditions. Obtaining healthy potato microplants starts in the first year according to a four-year seed-growing scheme of virus-free potato planting material. Breeding institutions organize this work. At the first stage, tubers are taken from obviously healthy plants and germinated. An apical meristem is isolated from sprouts under aseptic conditions and cultivated on nutrient media in phytotrons with controlled light and temperature conditions. Plants regenerated from the meristem are propagated by multiple cuttings according to the number of internodes to the required number of copies. Diagnosis of pathogen presence is mandatory. Healthy potato test plants are transferred to seed farms for mini-tubers, super-super elites and super-elites. The considered biotechnological approach, based on apical meristem method, is, in fact, a supportive selection and, being widely introduced into practice, makes it possible to annually provide farms with pathogen-free, high-quality potato planting material. 
Decoding of $S$. tuberosum and $P$. infestans genomes increased possibilities of genetic engineering to create genetically modified potato varieties with increased resistance to late blight. To transform potatoes with genes of closely related wild-tuberous forms of Solanum (section Petota Dumort.) a new term "cisgenesis" was proposed, which is designed to distinguish such forms of potato from genetically modified organisms obtained using foreign genes [9].

\section{Biotechnological approaches in controlling Colorado potato beetle}

Besides phytophthora, Colorado potato beetle, which can damage up to $40 \%$ yield in favorable years, is a serious biogenic risk for potatoes. Despite the rapid development of science, Colorado potato beetle still remains a harmful potato pest, and considerable funds are spent on combating it. Colorado potato beetle belongs to the objects of external and internal quarantine in the Republic of Belarus. It is very difficult to control it due to high fecundity, ability to go without food for a long time, fall into diapause for a long time, and travel considerable distances. In addition, Colorado potato beetle has few natural enemies, since eating Solanaceae plants containing poisonous solanine, Colorado beetles become poisonous to them. Complicating the fight against potato pests is the fact that with the beginning of spring, beetles wintering in soil come to soil surface not at the same time, but at intervals. In addition, some females overwinter already fertilized and immediately after reaching soil surface begin to lay eggs. Due to the climatic conditions of Belarusian Polesie, number of generations of Colorado potato beetle can be increased to three, which can further determine the duration of its harmfulness.

The traditional approach to reducing potato crop losses from the pest is chemical control methods. However, the use of chemicals against Colorado potato beetle causes the insect to quickly get used to the poison and also contributes to the preservation of more stable individuals that give more viable offspring. Over the past decades in the Republic of Belarus there has been an increase in number of Colorado potato beetle, a change in some bioecological features of pest development due to varying weather conditions of growing season, and formation of resistance to chemical agents. In this situation, microbiological agents and plant extracts for controlling Colorado potato beetle are considered to be the most suitable [10]. Most existing and newly developed microbial agents are based on strains of Bacillus thuringiensis soil bacterium, which is capable of producing Bt-toxin. This toxic protein differs depending on $B$. thuringiensis subspecies, therefore it has a high selectivity and allows to adjust the number of only certain insect types. When bacteria are consumed by susceptible insects, secreted Bt-toxin becomes active under the action of enzymes in alkaline conditions of digestive tract. In the active form, the toxin specifically binds to the receptors of epithelial cells and causes their destruction. Insects stop feeding and soon die, and Bt-toxin is destroyed in the sunlight. Bt-toxin does not have a negative effect on warm-blooded animals.

The development of genetic engineering methodology became it possible to detect and isolate genes encoding Bt-toxins, their modification and transfer to the plant genome. The first publications on practical developments in transferring potato varieties into transgenic status appeared in the early 90s of XX century. In particular, one such publication showed that genetically improved plants of the Russet Burbank potato variety 
contained a modified bacterial gene, B. thuringiensis var. tenebrionis encoding the control protein $L$. decemlineata Say, and were not damaged by Colorado potato beetle in the laboratory [11]. In transgenic varieties, the Bt-toxin gene is found in all cells, which means that it is able to express constantly, which allows the plant to protect itself from Colorado potato beetle and its larvae throughout the growing season. In all other respects, the transgenic variety does not differ from the original unmodified variety. In a review of biotechnological achievements of the first decade in crop production, it was noted that among other crops for which field trials and commercialization of transgenic plants were carried out from 1986 to 1995, potatoes accounted for 11\% [12].

The profitability of growing genetically modified plants on an industrial scale was immediately evaluated by companies in the USA, Argentina, Brazil, Canada, and India, which since 1996 have remained the undisputed leaders in expanding cultivated areas and a specific assortment of genetically engineered crops. According to the International Service for the Acquisition of Agribiotech Applications (ISAAA), in 2016 the cultivated area under genetically engineered crops in the world reached 185.1 million hectares, an increase of more than 100 times over ten years (for comparison, 1.7 million ha in 1996) [13]. The commercial benefits from genetically modified plants, due to increased yields while reducing chemical means of protection, as well as issues related to development of effective measures to maintain sustainable development, economic stability, encourage scientists from different countries, including the Republic of Belarus, to conduct research on genetic improvement of crop varieties of domestic selection. Such varieties form the basis of varietal resources of the country and compares favorably with their foreign counterparts, especially in terms of their adaptability to growing conditions, diseases resistance, and other characteristics.

The directions of research on genetic engineering of potatoes, carried out in scientific institutions of the Republic of Belarus, include the developing of transgenic lines based on Skarb Belarusian variety having resistance to Colorado potato beetle, as well as to late blight. In $2014-2015$, the genetically engineered potato line resistant to Colorado potato beetle and developed at the Institute of Genetics and Cytology of the National Academy of Sciences of Belarus, was tested in an experimental field that met safety requirements. The transgenic line was obtained by introducing the Cry3aM gene, whose donor was bacterium $B$. thuringiensis var. tenebrionis, into the potato plant genome, under the control of the CaMV 35S promoter from cauliflower mosaic virus. The foreign gene expresses the Bt-endotoxin protein, which exhibits insecticidal properties against Colorado potato beetle and does not affect other insects.

\section{Assessment of potential risks associated with the use of transgenic organisms in the Republic of Belarus}

Considering the short global practice of using genetically modified plants, as well as the fact that potatoes are a significant food crop for consumers, safety of its genetically modified varieties should not only be ensured by scientists, but also guaranteed at the state level. In the Republic of Belarus for the period following the accession in May 2002 to the Cartagena Protocol on Biosafety to the Convention on Biological Diversity, a National Security System was created that included legislative and regulatory components to regulate safety of genetic engineering activities and aimed at protecting 
human health and the environment. The legislative acts are aimed at creating the legal and organizational foundations of safety carried out in research institutions, as well as at an objective assessment of potential risks of genetically engineered organisms that are only released for environmental tests in the field and to the market.

Under Belarusian law, the procedure for assessing environmental risks and risks to human health is carried out twice. For the first time, the standard risk assessment procedure [14] is carried out before the genetically modified organism is released into the environment for testing on specially equipped experimental fields that meet world biosafety requirements. For this, the applicant scientific organization submits to the expert council of the Ministry of Natural Resources and Environmental Protection a full study on the risk assessment of the possible harmful effects of the developed genetic engineering organism, which is further evaluated by experts from among scientific institutions competent in this field. After it is considered at a meeting of the expert council of the Ministry of Natural Resources, at which it is decided whether or not the release of such an organism is permissible. Risks are reassessed before releasing genetically modified organisms into agricultural production. Genetically engineered organisms that have undergone a full cycle of research and are admitted to the market should not have negative effects on human health. All information on risk assessment is freely available on the website of the National Biosafety Coordination Center of the Republic of Belarus (http://www.biosafety.by). The National Biosafety Coordination Center was established in 1998 with the aim of ensuring the effective participation of the Republic of Belarus in solving the global problem of preserving biological diversity and coordinating activities related to the safety of using the achievements of modern biotechnology.

\section{Conclusions}

The current global trend in the development of plant protection methods is associated with increasing developing and implementation of transgenic organisms, the genome of which contains foreign genes to ensure their resistance to insect pests and pathogens. The use of genetic engineering methods aimed at reducing biogenic agroecological risks, in turn, raises concerns related to the ability of genetically modified organisms to have an adverse effect on conservation and sustainable use of biological diversity, and human health risks. It should be noted that the gene itself does not carry risks, since it consists of a sequence of nucleotides that are the same in all living organisms. Potential risks may arise due to the non-specific insertion of a new gene into the plant genome, i.e. insertion can occur anywhere in the DNA. The result of the insertion can be both favorable and undesirable consequences. If a foreign gene is inserted into a region of DNA that already encodes a gene, this can lead to its silencing, and, as a result, to termination of synthesis of a certain substance, which should not be observed when a new gene is inserted into a silent part of the genome. If the initial unmodified organism, into which the new gene is transformed, initially has undesirable traits, then with the integration of the gene such properties can be enhanced. That is why it is imperative that when assessing risks to human health, allergological and toxico- 
logical specialized tests are carried out, including animal studies. At the same time, the duration of the research will be increased if the parent organism, in which the new gene is inserted, is initially allergenic, has an increased level of anti-nutritional substances (e.g. soy), since after gene inserting, they can increase. It is also imperative to develop a molecular method that can effectively identify and track in the future the distribution on the market of a genetically modified organism and products derived from it. Currently, there are 18 specialized laboratories for detection of genetically modified organisms accredited by state or international standards in the republic. Another group of potential risks is associated with the safety of using genetically engineered organisms. Since transgenic plants begin to multiply in the environment, the risks associated with the consequences of transgene transfer during pollination for closely related cultural and wild species should be evaluated. Therefore, the transgenic organisms being developed undergo mandatory expert assessment, which involves consideration of all potential environmental and human health risks that may appear after insertion of a specific new gene and the new sign that will appear. When transgenic plants are released into the environment, there must be full scientific certainty about absence of threat of serious or irreversible damage. Summing up the issue of potential risks associated with the use of organisms and products of genetic technologies, we would like to note that all transgenic potato lines obtained in the Republic of Belarus are tested in laboratory conditions and on experimental fields that meet safety requirements. Since potato is an introduced species for Belarus, there is no possibility of uncontrolled transfer of its genetic material, including and transgenic, wild plant species growing in natural biocenoses. The need to use genetic engineering methods is associated with an exacerbation of biogenic agroecological risks, which can be reduced through the strategy of proactive introgressive selection based on cell-engineering and molecular methods.

\section{Проблема урожайности в картофелеводстве Республики Беларусь и России}

На фоне возрастающих потенциальных рисков, обусловленных неблагоприятными изменениями, происходящими в биосфере, одной из важнейших задач является получение высоких урожаев растений. От продуктивности растениеводства напрямую зависит эффективность всего сельскохозяйственного производства. Растительный организм, способный трансформировать энергию солнца в энергию органических соединений, - основополагающее звено в получении продуктов питания, кормов, сырья, топлива, лекарственных средств. Интенсификация растениеводства в современных условиях должна базироваться на разумном сочетании традиционных подходов с новыми технологиями.

Картофель (Solanum tuberosum L.) - вторая по важности сельскохозяйственная культура в Республике Беларусь, лишь в последние пять лет незначительно уступающая рапсу. Брестская область стабильно занимает второе место по площади, занятой под выращивание картофеля, в хозяйствах всех категорий. Однако, по данным Белстата (рис. 1), урожайность картофеля в условиях Брестской области снижена в сравнении с данным показателем по Республике Беларусь и ряду областей. 


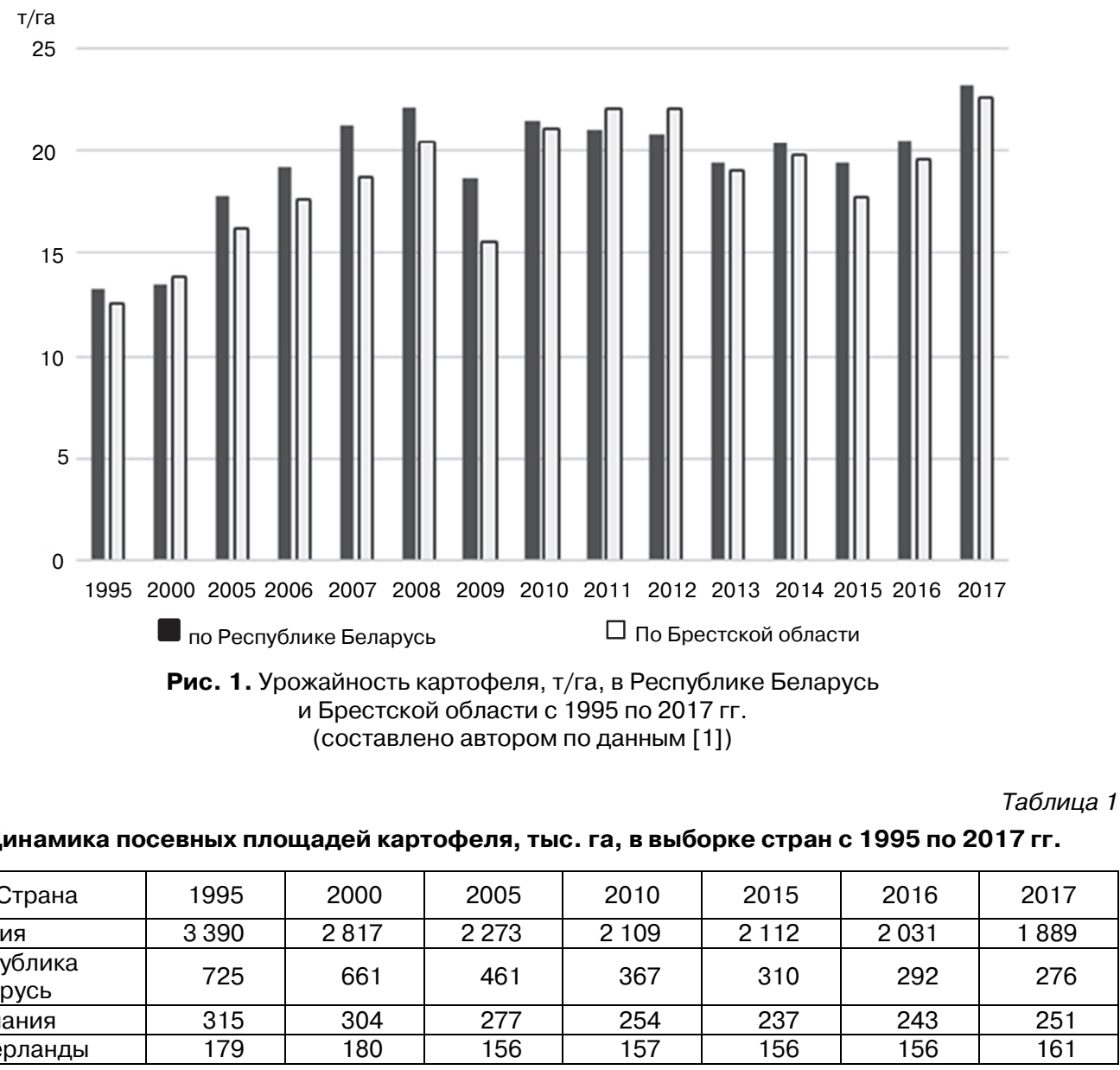

Составлено автором по данным [2].

Таблица 2

Динамика урожайности картофеля, т/га, в выборке стран с 1995 по 2017 гг.

\begin{tabular}{|l|c|c|c|c|c|c|c|}
\hline \multicolumn{1}{|c|}{ Страна } & 1995 & 2000 & 2005 & 2010 & 2015 & 2016 & 2017 \\
\hline Россия & 11,8 & 10,5 & 12,4 & 10,0 & 15,9 & 15,3 & 15,7 \\
\hline $\begin{array}{l}\text { Республика } \\
\text { Беларусь }\end{array}$ & 13,1 & 13,2 & 17,7 & 21,4 & 19,4 & 20,5 & 23,2 \\
\hline Германия & 31,4 & 43,3 & 42,0 & 39,9 & 43,8 & 44,4 & 46,8 \\
\hline Нидерланды & 41,0 & 45,7 & 43,4 & 43,6 & 42,7 & 42,0 & 46,0 \\
\hline Западная Европа & 35,1 & 42,7 & 42,1 & 41,2 & 42,9 & 41,3 & 44,9 \\
\hline
\end{tabular}

Составлено автором по данным [2].

Проблема урожайности в картофелеводческой отросли Республики Беларусь и России обостряется на фоне наблюдаемой тенденции к сокращению посевных площадей. В период с 1995 по 2015 гг. занимаемые картофелем площади в Республике Беларусь уменьшились в 2,3 раза, в России - в 1,6 раза и продолжают ежегодно сокращаться (табл. 1). Выполнение объемов собственного производства картофеля, определенных национальными доктринами продовольственной безопасности двух стран, невозможно без повышения урожайности. Несмотря 
на рост данного показателя в 2015 г. по отношению к 1995 г. (в Республике Беларусь - на 48\%, в России - на $34 \%$ ), средняя урожайность картофеля в двух странах в разы меньше, чем среднее значение по странам Западной Европы (табл. 2). Кроме того, как показывают приведенные в таблицах статистические данные Продовольственной и сельскохозяйственной организации ОOH (FAO — Food and Agriculture Organization), в Германии и Нидерландах - крупных производителях картофеля среди Европейских стран - снижение посевных площадей за 20 лет было не столь высоким, а начиная с 2015 г. прослеживается обратная тенденция. Высокие средние показатели урожайности картофеля в данных странах позволяют достигать значительной производительности на сравнительно небольших посевных площадях.

Обозначенная проблема низкой урожайности картофеля в Республике Беларусь и России помимо технологических и организационно-экономических факторов напрямую связана с биогенными рисками возделывания данной культуры. Недобор урожая картофеля обусловлен нарастанием вредоносности ряда заболеваний, вызываемых грибными, бактериальными и вирусными патогенами, а также распространенностью насекомых-вредителей. Рассмотрим предлагаемые современной биотехнологией пути снижения негативного влияния двух наиболее распространенных вредоносных объектов: колорадского жука (Leptinotarsa decemlineata Say) и фитофторы (Phytophthora infestans (Mont.) de Bary), приводящих к значительным потерям урожая картофеля.

\section{Биотехнологические подходы в борьбе с фитофторозом}

Фитофтороз относится к одним из вредоноснейших заболеваний картофеля. Фитофтороз поражает надземную часть растений и тем самым уменьшает ассимилирующую поверхность в период клубнеобразования, а также вызывает гниение клубней во время хранения. В Республике Беларуси сильные вспышки болезни с потерями $30 \ldots 50 \%$ урожая наблюдаются через каждые $2-3$ года.

К основным способам борьбы с фитофторозом, активно используемым на протяжении нескольких десятилетий XX в. и имеющим продолжение в новом столетии, относятся возделывание устойчивых сортов картофеля и использование фунгицидов. Последний способ, несмотря на эффективность, небезопасен для здоровья человека и порождает проблему увеличения химической нагрузки на агроценозы, и, как следствие, ухудшения экологического состояния окружающей среды. Поэтому для устойчивого развития картофелеводства в современных условиях наравне с применением эффективных агротехнических мероприятий требуется создание новых высокоустойчивых к P. Infestans сортов картофеля, что позволит существенно сократить применение химических обработок на протяжении вегетации растений.

Устойчивость к P. infestans ранее созданных сортов определялась присутствием R-генов, перенесенных методом отдаленной гибридизации из дикорастущего сородича картофеля Solanum demissum [3]. Однако высокая изменчивость $P$. infestans проявилась в образовании новых форм патогена, способных преодолевать защитные реакции устойчивых сортов, созданных на основе R-генов S. demis- 
sum. По данным Ю.Т. Дьякова, частота спонтанных мутаций у P. infestans по одному локусу на 1 га достигает 1000 . Именно высокая скорость мутирования патогена способна обеспечить необходимый для всевозможных адаптаций уровень изменчивости [4]. Процесс изменчивости резко усилился, начиная с 1984 г., когда из Мексики в области интенсивного возделывания картофеля мигрировали новые популяции фитофторы с двумя типами полового процесса А1 и А2 [3]. Появление в Республике Беларусь А2 типа значительно усугубило вредоносность фитофтороза, поскольку усложнился расовый состав, расширился спектр вирулентности, повысилась агрессивность патогена, а также его резистентность к существующим пестицидам [5].

Перспективной стратегией, противостоящей быстрой потере устойчивости растений картофеля к фитофторозу, является создание новых сортов, надолго сохраняющих высокую устойчивость к многим расам фитофторы. Объединение нескольких генов устойчивости из дикорастущих сородичей картофеля в одном растении (пирамидирование генов) делает устойчивость долговременной, поскольку совокупность перенесенных генов обеспечивает распознавание различных рас патогена. Изменение расового состава патогена в агроценозе не будет приводить к существенному снижению продуктивности растений с долговременной устойчивостью. Такую селекцию называют упреждающей [6]. Результативность интрогрессивной селекции картофеля может быть повышена за счет создания нового исходного материла с комплексной устойчивостью к фитофторозу как надземных частей растения, так и клубней. Также определяющую роль в развитии стратегии повышения устойчивости картофеля к фитофторозу играет целенаправленный поиск источников ценных генов с помощью методов маркер-сопутствующей селекции. Молекулярные маркеры позволяют надежно различать формы растений, устойчивые к различным патотипам одного и того же возбудителя болезни, что существенно ускоряет отбор устойчивых генотипов и включение их в селекционный процесс.

В практической селекции картофеля на протяжении нескольких десятков лет используется межвидовая гибридизация. При этом перенос генов устойчивости из дикорастущих видов рода Solanum, произрастающих в Северной и Южной Америке, в $S$. tuberosum при половой гибридизации, как правило, ограничен из-за физиологической и генетической несовместимости. Преодоление несовместимости при отдаленной гибридизации культурного тетраплоидного картофеля с дикорастущими видами стало возможным благодаря разработке ряда биотехнологических методов.

Метод соматической гибридизации основан на слиянии протопластов, изолированных из соматических клеток растений различных видов в условиях in vitro. Соматическая гибридизация в обход полового процесса позволяет создавать новый исходный материал (сложные межвидовые гибриды из трех и более родительских клеток) с ценными признаками от диких видов для расширения генетических возможностей селекции картофеля. К преимуществам соматической гибридизации относится объединение в одном геноме не только генов культурного картофеля и филогенетически отдаленных диких сородичей, которых у картофеля 
более 230, но и генов органелл цитоплазмы (митохондрий, пластид), что обеспечивает создание качественно новых межвидовых гибридов [7]. Межвидовые соматические гибриды картофеля получены во многих странах, в т.ч. и Республике Беларусь. В НПЦ НАН Беларуси по картофелеводству и плодоовощеводству методом соматической гибридизации созданы соматические гибриды с 10 дикими видами картофеля, малодоступными для половой гибридизации. Несмотря на привлекательность соматической гибридизации, создание сортов растений, в том числе и картофеля, полученных на основе соматических гибридов, остается редким явлением, поскольку существует проблема с фертильностью соматических гибридов и их способностью к генерации жизнеспособного потомства при скрещивании с культурным картофелем [8].

Другим экологически оправданным биотехнологическим способом борьбы с фитофторозом клубней, снижающим качество посадочного материала во время хранения, является метод микроклонального размножения пробирочных растений, позволяющий получить в достаточном количестве оздоровленный материал не только от грибных, но и вирусных патогенов.

Микроклональное размножение позволяет получить в условиях in vitro генетически идентичные материнскому растения-клоны. Включает три этапа: введение в культуру экспланта клонируемого растения; регенерация микропобега и его размножение в необходимом количестве копий; стимуляция корнеобразования у пробирочных растений и адаптация их к условиям in vivo. Получение оздоровленных пробирочных растений картофеля происходит в первый год согласно четырехлетней схеме семеноводства безвирусного посадочного материала картофеля. Организуют эту работу селекционные учреждения. На первом этапе отбирают клубни от заведомо здоровых растений и проращивают. Из ростков в асептических условиях выделяют апикальную меристему и культивируют на питательных средах в фитотронах с контролируемыми световым и температурным режимами. Регенерированные из меристем растения размножают многократным черенкованием по числу междоузлий до необходимого количества копий. Обязательным является диагностика на наличие патогенов. Здоровые пробирочные растения картофеля передаются семеноводческим хозяйствам для получения мини-клубней, супер-суперэлиты и суперэлиты. Рассмотренный биотехнологический подход, основанный на методе апикальных меристем, по сути, является поддерживающей селекцией и, будучи широко внедренным в практику, позволяет ежегодно обеспечивать хозяйства оздоровленным, качественным сортовым посадочным материалом картофеля.

С расшифровкой геномов $S$. tuberosum и $P$. infestans расширились возможности генной инженерии по созданию генетически модифицированных сортов картофеля с повышенной устойчивостью к фитофторозу. Для трансформации картофеля генами близкородственных дикорастущих клубненосных форм Solanum (секции Petota Dumort.) предложен новый термин «цисгенез», призванный отличать такие формы картофеля от генетически модифицированных организмов, полученных с использованием чужеродных генов [9]. 


\section{Биотехнологические подходы в борьбе с колорадским жуком}

Помимо фитофторы серьезным биогенным риском для картофеля во многих странах является колорадский жук, который в благоприятные годы способен уничтожить до 40\% урожая. Несмотря на стремительное развитие науки, колорадский жук до сих пор остается опасным вредителем картофеля, на борьбу с которым тратятся немалые средства. Колорадский жук как опасный вредитель картофеля относится к объектам внешнего и внутреннего карантина в Республике Беларусь. Бороться с ним в связи с его высокой плодовитостью, способностью длительно обходиться без пищи, впадать в диапаузу на продолжительный срок и перемещаться на значительные расстояния очень затруднительно. К тому же у колорадского жука мало естественных врагов. Питаясь пасленовыми, содержащими ядовитый соланин, колорадские жуки становятся для них ядовитыми. Затрудняет борьбу с вредителем картофеля и тот факт, что с началом весны жуки, зимующие в почве, выходят на поверхность земли не одновременно, а с интервалами. Кроме того, некоторые самки зимуют уже оплодотворенными и сразу после выхода на поверхность начинают откладывать яйца. В связи с климатическими особенностями Белорусского Полесья количество генераций у колорадского жука может быть увеличено до трех, что еще больше может обусловить продолжительность его вредоносности.

Традиционным подходом, направленным на сокращение потерь урожая картофеля от вредителя, являются химические методы защиты. Однако использование химических препаратов против колорадского жука вызывает у насекомого быстрое привыкание к яду и способствует к тому же сохранению более устойчивых особей, дающих более жизнеспособное потомство. За последние десятилетия в Республике Беларусь произошло увеличение распространенности колорадского жука, изменение некоторых биоэкологических особенностей развития вредителя вследствие варьирования погодных условий вегетационного сезона, формирование резистентности к химическим средствам защиты. В сложившейся ситуации наиболее подходящим считается использование микробиологических препаратов и растительных экстрактов с включением их в экологизированную систему защиты картофеля от колорадского жука [10]. Большинство существующих и вновь разрабатываемых микробных препаратов создаются на основе штаммов почвенной бактерии Bacillus thuringiensis, которые способны вырабатывать белок, названный $\mathrm{Bt}$-токсином. Этот токсический белок отличается в зависимости от подвида B. thuringiensis, производящего его, поэтому обладает высокой избирательностью действия и позволяет регулировать численность только определенных видов насекомых. Когда бактерии потребляются восприимчивыми насекомыми, выделяемый Вt-токсин становится активным под действием ферментов в щелочных условиях пищеварительного тракта. В активной форме токсин специфически связывается с рецепторами эпителиальных клеток и вызывает их разрушение. Насекомые перестают питаться и вскоре погибают, a Bt-токсин разрушается под действием солнечного света. На теплокровных животных Bt-токсин не оказывает негативного действия. 
С разработкой методологии генетической инженерии стало возможным обнаружение и выделение генов, кодирующих Bt-токсины, их модификация и перенос в геном растений. Первые публикации о практических наработках по переводу сортов картофеля в статус трансгенных появились в начале 90-х гг. XX в. В частности, в одной из таких публикаций показано, что генетически улучшенные растения сорта картофеля Russet Burbank содержали модифицированный бактериальный ген $B$. thuringiensis var. tenebrionis, кодирующий белок-контролер L. decemlineata Say, и не повреждались колорадским жуком в лабораторных условиях [11]. У трансгенных сортов ген Вt-токсина находится во всех клетках, а значит, способен эксперессироваться постоянно, что позволяет растению защитить себя от колорадского жука и его личинок на протяжении всей вегетации. По всем остальным признакам трансгенный сорт не отличается от исходного немодифицированного сорта. В обзоре достижений первого десятилетия биотехнологии в растениеводстве отмечено, что в мировом масштабе среди других культур, для которых проведены полевые испытания и коммерциализация трансгенных растений с 1986 по 1995 г., картофель составлял 11\% [12].

Прибыльность выращивания генетически модифицированных растений в производственных масштабах сразу была оценена компаниями США, Аргентины, Бразилии, Канады, Индии, которые с 1996 г. остаются безусловными лидерами по расширению посевных площадей и видового сортимента генно-инженерных культур. По данным Международной службы по внедрению агробиотехнологических разработок (ISAAA - International Service for the Acquisition of Agribiotech Applications), в 2016 г. посевные площади под генно-инженерными культурами в мире достигли 185,1 млн га, увеличившись за десять лет более чем в 100 раз (для сравнения 1,7 млн га в 1996 г.) [13]. Коммерческая выгода от использования генетически модифицированных растений, обусловленная повышением урожайности при сокращении затрат на применение химических средств защиты, а также вопросы, связанные с выработкой эффективных мер по поддержанию устойчивого развития, экономической стабильности, побуждают ученых разных стран, в т.ч. и Республики Беларусь, к проведению исследований по генетическому улучшению сортов сельскохозяйственных культур отечественной селекции. Такие сорта составляют основу сортовых ресурсов страны и выгодно отличаются от зарубежных аналогов, особенно по уровню их адаптивности к условиям выращивания, устойчивости к болезням и ряду других признаков.

К направлениям исследований по генетической инженерии картофеля, проводимых в научных учреждениях Республики Беларусь, относятся создание трансгенных линий на основе сорта белорусской селекции Скарб с устойчивостью к колорадскому жуку, а также к фитофторозу. В 2014-2015 гг. проведены испытания созданной в Институте генетики и цитологии НАН Беларуси генно-инженерной линии картофеля, устойчивой к колорадскому жуку, на опытном поле, соответствующем требованиям безопасности. Трансгенная линия получена путем введения в геном растений картофеля сорта Скарб гена Cry3aM, донором которого была бактерия $B$. thuringiensis var. tenebrionis, под контролем CaMV 35S промотора от вируса мозаики цветной капусты. Чужеродный ген экспрессирует белок Bt-эндотоксин, который проявляет инсектицидные свойства по отношению к колорадскому жуку и не действует на других насекомых. 


\section{Оценка потенциальных рисков, связанных с использованием трансгенных организмов, в Республике Беларусь}

Принимая во внимание короткую мировую практику использования генетически модифицированных растений, а также то, что картофель является значимой для потребителей продовольственной культурой, безопасность его генетически модифицированных сортов должна быть не только обеспечена со стороны ученых, но и гарантирована на уровне государства. В Республике Беларусь за период, прошедший после присоединения в мае 2002 г. к Картахенскому протоколу по биобезопасности к Конвенции о биологическом разнообразии, была создана Национальная система безопасности, включающая законодательную и нормативно-регламентную составляющие регулирования безопасности генно-инженерной деятельности и направленная на охрану здоровья человека и окружающей среды. Действие законодательных актов нацелено на создание правовых и организационных основ безопасности, проводимой в научных учреждениях деятельности, а также на объективную оценку потенциальных рисков генно-инженерных организмов, только выпускаемых для экологических испытаний в полевых условиях и высвобождаемых на рынок.

По белорусскому законодательству процедура оценки экологических рисков и рисков для здоровья человека проводится дважды. Первый раз стандартная процедура оценки рисков [14] проводится перед высвобождением генетически модифицированного организма в окружающую среду для проведения испытаний на специально оборудованных опытных полях, соответствующих мировым требованиям биобезопасности. Для этого научная организация-заявитель представляет в экспертный совет Министерства природных ресурсов и охраны окружающей среды полное исследование об оценке риска возможных вредных воздействий созданного генно-инженерного организма, которое далее оценивается одним из экспертов либо экспертами из числа научных учреждений, компетентных в данной области, после чего рассматривается на заседании экспертного совета Минприроды, на котором решается, допустимо либо нет высвобождение такого организма. Повторно риски оцениваются перед выпуском генетически модифицированных организмов в сельскохозяйственное производство. У генно-инженерных организмов, прошедших полный цикл исследований и допущенных на рынок, не должно быть выявлено отрицательных эффектов на здоровье человека. Вся информация по оценке рисков размещается в свободном доступе на вебсайте Национального координационного центра биобезопасности Республики Беларусь (http://www.biosafety.by). Национальный координационный центр биобезопасности был создан в 1998 г. с целью обеспечения эффективного участия Республики Беларусь в решении глобальной проблемы сохранения биологического разнообразия и координации деятельности, связанной с безопасностью использования достижений современной биотехнологии.

\section{Выводы}

Современная мировая тенденция по разработке способов защиты растений связана с наращиванием темпов создания и внедрения в практику трансгенных организмов, в геном которых интегрированы чужеродные гены, обеспечивающие 
их устойчивость к насекомым-вредителям и патогенам. Использование генноинженерных методов, направленных на снижение биогенных агроэкологических рисков, порождает в свою очередь опасения, связанные как со способностью генетически модифицированных организмов оказать неблагоприятное воздействие на сохранение и устойчивое использование биологического разнообразия, так и возникновением рисков для здоровья человека. Следует отметить, что сам по себе встроенный ген не несет рисков, поскольку состоит из последовательности нуклеотидов, которые одинаковы у всех живых организмов. Потенциальные риски могут возникать из-за неспецифического встраивания нового гена в геноме растения, т.е. вставка может произойти в любом участке ДНК. Результатом вставки могут быть как благоприятные, так и нежелательные последствия. Если чужеродный ген встраивается в область ДНК, которая уже кодирует какой-то ген, то это может привести к его замолканию, и, как следствие, к прекращению синтеза определенного вещества, чего не должно наблюдаться при встраивании нового гена в молчащий участок генома. Если исходный немодифицированный организм, в который трансформируется новый ген, изначально обладает нежелательными признаками, то при интеграции гена такие свойства могут усилиться. Именно поэтому обязательно при оценке рисков для здоровья человека проводятся аллергологические и токсилогические специализированные тесты, в том числе исследования на животных. При этом длительность исследований будет увеличена в том случае, если родительский организм, в который встроен новый ген, изначально обладает аллергенностью, имеет повышенный уровень антипитательных веществ (например, соя), так как при встройке гена они могут усилиться. Также обязательной является разработка молекулярного метода, позволяющего эффективно выявлять и прослеживать в дальнейшем распространение на рынке созданного генетически модифицированного организма и продукты, получаемые на его основе. В настоящее время в республике функционируют 18 специализированных лабораторий по дететкции генетически модифицированных организмов, аккредитованных по государственным или международным стандартам. Другая группа потенциальных рисков связана с безопасностью использования генно-инженерных организмов. Поскольку при высвобождении в окружающую среду трансгенные растения начинают размножаться, то должны быть оценены риски, связанные с последствием переноса трансгена при опылении для близкородственных культурных и диких видов. Поэтому разрабатываемые трансгенные организмы в обязательном порядке проходят экспертную оценку, предполагающую рассмотрение всех потенциальных экологических рисков и рисков для здоровья человека, которые могут появиться в связи со встройкой конкретного нового гена и тем новым признаком, который будет проявляться. При высвобождении в окружающую среду трансгенных растений должна быть полная научная уверенность в отсутствии угрозы серьезного или необратимого ущерба. Подводя итог вопросу возможных потенциальных рисков, связанных с использованием организмов и продуктов генных технологий, хотелось бы отметить, что все получаемые в Республике Беларусь трансгенные линии картофеля проходят исследования в лабораторных условиях и на опытных полях, соответствующих требованиям безопасности. Поскольку картофель является интродуцированным видом для Беларуси, то отсутствует возможность неконтролируемого переноса его генетического материала, 
в т.ч. и трансгенного, диким видам растений, произрастающим в естественных биоценозах. Потребность использования генно-инженерных методов связана с обострением биогенных агроэкологических рисков, в снижении которых важным подходом является стратегия упреждающей интрогрессивной селекции, основанной на клеточно-инженерных и молекулярных методах.

\section{References}

1. BELSTAT. Available from: http://www.belstat.gov.by/ofitsialnaya-statistika/ [Accessed 1st August 2019].

2. FAOSTAT. Available from: http://www.fao.org/faostat/ru/\#data/QC [Accessed 29th October 2019].

3. Khavkin EE. Resistance of potatoes to black eye rot by view of molecular biotechnologist. In: Kharchenko PN. (ed.) Problemy agrobiotekhnologii [Problems of agrobiotechnology]. Moscow: VNIISB Publ.; 2012. p. 69-92. (In Russ).

4. Dyakov YT, Elanskiy SN. Population genetics Phytophthora infestans. In: Dyakov YT, Sergeeva YV. (ed.) Mikologiya segodnya [Mycology today]. Moscow: National Mycology Academy Publ.; 2007. 1:107-139. (In Russ).

5. Chashinskiy AV. Mexican varieties S. stoloniferum and S. polytrichon for creation of initial material resistant to black eye rot. In: Turko SA. (ed.) Kartofelevodstvo [Potato Growing]. Minsk: Research and Practical Centre of National Academy of Sciences of Belarus for Potato, Fruit and Vegetable Growing; 2015. 23:56-68. (In Russ).

6. Fadina OA, Beketova MP, Sokolova EA, Kuznetsova MA, Smetanina TI, Rogozina EV, Khavkin EE. Anticipatory breeding: molecular markers as a tool in developing donors of potato (Solanum tuberosum L.) late blight resistance from complex interspecific hybrids. Agricultural Biology.2017; 52(1):84 -94. (In Russ). doi: 10.15389/agrobiology.2017.1.84rus

7. Yakovleva GA. Somatic hybridization and cell selection of potatoes (Solanum tuberosum L.). In: Kilchevskij AV, Khotyleva LV. (ed.) Biotekhnologiya v selektsii rastenii. Kletochnaya inzheneriya [Biotechnology in plant breeding. Cell engineering]. Minsk: Belorusskaya nauka Publ.; 2012. 3:217-250. (In Russ).

8. Yakovleva GA, Semanyuk TV, Kondratyuk AV, Bashko DV, Rodkina IA. Genital breeding of somatic hybrids and new potatoes initial forms creation. In: Turko SA. (ed.) Kartofelevodstvo [Potato Growing]. Minsk: Research and Practical Centre of National Academy of Sciences of Belarus for Potato, Fruit and Vegetable Growing; 2017. 25:94-104. (In Russ).

9. Jacobsen E, Schouten HJ. Cisgenesis, a new tool for traditional plant breeding, should be exempted from the regulation on genetically modified organisms in a step by step approach. Potato Research. 2008; 51:75-88. doi: 10.1007/s11540-008-9097-y

10. Yankovskaya EN, Vojtka DV, Brechko EV, Elisovetskaya DS, Nastas TN. Ontogenetic peculiarities of colorado potato beetle susceptibility to bio-preparation and plant extracts. In: Turko SA. (ed.) Kartofelevodstvo [Potato Growing]. Minsk: Research and Practical Centre of National Academy of Sciences of Belarus for Potato, Fruit and Vegetable Growing; 2014; 22:78-88. (In Russ).

11. Perlak FJ, Stone TB, Muskopf YM, Petersen LJ, Parker GB, McPherson SA, Wyman J, Love S, Reed G, Biever D, Fischhoff DA. Genetically improved potatoes: protection from damage by colorado potato beetles. Plant Molecular Biology. 1993; 22(2):313-321. doi: 10.1007/BF00014938

12. James C, Krattiger AF. Global Review of the Field Testing and Commercialization of Transgenic Plants, 1986 to 1995: The First Decade of Crop Biotechnology. ISAAA Briefs No 1. Ithaca, NY: ISAAA; 1996.

13. ISAAA. Global Status of Commercialized Biotech/GM Crops: 2016. ISAAA Brief No. 52. Ithaca, NY: ISAAA; 2016. 
14. Mozgova GV. Otsenka riskov vozdeistviya GMO na sokhranenie I ustoichivoe ispol'zovanie biologicheskogo raznoobraziya, s uchetom riskov dlya zdorov'ya cheloveka [Risk assessment of the impact of GMOs on the conservation and sustainable use of biological diversity, considering risks to human health]. Minsk: Pravoiekonomika Publ.; 2014. (In Russ).

\section{Библиографический список}

1. Национальный статистический комитет Республики Беларусь. Режим доступа: http://www.belstat.gov.by/ofitsialnaya-statistika/. Дата обращения: 01.08.2019.

2. FAOSTAT // Продовольственная и сельскохозяйственная организация ООН. Режим доступа: http://www.fao.org/faostat/ru/\#data/QC Дата обращения: 29.10.2019.

3. Хавкин Э.Е. Устойчивость картофеля к фитофторозу глазами молекулярного биотехнолога // Проблемы агробиотехнологии / под ред. П.Н. Харченко. М.: ВНИИСБ, 2012. С. 69-92.

4. Дьяков Ю.Т., Еланский С.Н. Популяционная генетика Phytophthora infestans // Микология сегодня / под ред. Ю.Т. Дьякова, Ю.В. Сергеева. М.: Национальная академия микологии, 2007. Т. 1. С. $107-139$.

5. Чашинский A.B. Использование мексиканских видов S. stoloniferum и S. polytrichon при создании исходного материала, устойчивого к фитофторозу // Картофелеводство: сб. науч. тр. / под ред. С.А. Турко. Минск: Науч.-практ. центр Нац. акад. наук Беларуси по картофелеводству и плодоовощеводству, 2015. Т. 23. С. 56-68.

6. Фадина О.А., Бекетова М.П., Соколова Е.А., Кузнецова М.А., Т.И. Сметанина Т.И., Рогозина Е.В., Хавкин Э.Е. Упреждающая селекция: использование молекулярных маркеров при создании доноров устойчивости картофеля (Solanum tuberosum L.) к фитофторозу на основе сложных межвидовых гибридов // Сельскохозяйственная биология. 2017. Т. 52. № 1. C. 84 -94. doi: 10.15389/agrobiology.2017.1.84rus

7. Яковлева Г.А. Соматическая гибридизация и клеточная селекция картофеля (Solanum tuberosum L.) // Биотехнология в селекции растений. Клеточная инженерия / науч. ред. А.В. Кильчевский, Л.В. Хотылева. Минск: Белорусская наука, 2012. Т. 3. С. 217-250.

8. Яковлева Г.А., Семанюк Т.В., Кондратюк А.В., Башко Д.В., Родькина И.А. Селекция генеративного потомства соматических гибридов и создание новых исходных форм картофеля // Картофелеводство: сб. науч. тр. / под ред. С.А. Турко. Минск: Науч.-практ. центр Нац. акад. наук Беларуси по картофелеводству и плодоовощеводству, 2017. Т. 25. C. $94-104$.

9. Jacobsen E., Schouten H.J. Cisgenesis, a new tool for traditional plant breeding, should be exempted from the regulation on genetically modified organisms in a step by step approach // Potato Research. 2008. Vol. 51. P. 75-88. doi: 10.1007/s11540-008-9097-y

10. Янковская Е.Н., Войтка Д.В., Бречко Е.В., Елисовецкая Д.С., Настас Т.Н. Онтогенетические особенности восприимчивости колорадского жука к воздействию биопрепаратов и растительных экстрактов // под ред. С.А. Турко. Минск: Науч.-практ. центр Нац. акад. наук Беларуси по картофелеводству и плодоовощеводству, 2014. Т. 22. С. $78-88$.

11. Perlak F.J., Stone T.B., Muskopf Y.M., Petersen L.J., Parker G.B., McPherson S.A., Wyman J., Love S., Reed G., Biever D., Fischhoff D.A. Genetically improved potatoes: protection from damage by colorado potato beetles // Plant Molecular Biology. 1993. Vol. 22. No. 2. P. 313321. doi: 10.1007/BF00014938

12. James C., Krattiger A.F. Global Review of the Field Testing and Commercialization of Transgenic Plants, 1986 to 1995: The First Decade of Crop Biotechnology // ISAAA Briefs No. 1. ISAAA: Ithaca, NY, 1996. 31 p. Available from: http://www.isaaa.org/resources/publications/ briefs/01/download/isaaa-brief-01-1996.pdf

13. Global Status of Commercialized Biotech/GM Crops: 2016. ISAAA Brief No. 52. ISAAA: Ithaca, NY, 2016. 135 p. Available from: http://www.isaaa.org/resources/publications/briefs/ 52/download/isaaa-brief-52-2016.pdf 
14. Мозгова Г.В. Оценка рисков воздействия ГМО на сохранение и устойчивое использование биологического разнообразия, с учетом рисков для здоровья человека. Минск: Право и экономика, 2014. 58 с.

\section{About the authors:}

Lenivko Svetlana Mikhailovna - Candidate of Biological Sciences, Associate Professor, Department of Zoology and Genetics, Brest State A.S. Pushkin University, 21, Cosmonavtov avenue, Brest, 224016, Republic of Belarus; e-mail: lenivko@brsu.brest.by

Boyko Vladimir Ivanovich - Candidate of Biological Sciences, Associate Professor, Department of Botany and Ecology, Brest State A.S. Pushkin University, 21, Cosmonavtov avenue, Brest, 224016, Republic of Belarus; e-mail: boikobio@yandex.by

\section{Об авторах:}

Ленивко Светлана Михайловна - кандидат биологических наук, доцент кафедры зоологии и генетики, Брестский государственный университет имени А.С. Пушкина, Республика Беларусь, 224016, г. Брест, Бульвар Космонавтов, д. 21; e-mail: lenivko@brsu.brest.by

Бойко Владимир Иванович - кандидат биологических наук, доцент кафедры ботаники и экологии, Брестский государственный университет имени А.С. Пушкина, Республика Беларусь, 224016, г. Брест, Бульвар Космонавтов, д. 21; e-mail: boikobio@yandex.by 